\title{
Ustanowienie stanowej prowincjonalnej kasy pożyczkowej na Śląsku w 1854 roku
}

Powodzie nękały ludzkość od najdawniejszych czasów, co uwieczniał już opis potopu w Biblii. Dotykały one także Śląsk od najdawniejszych wieków, powtarzały się one cyklicznie w każdym stuleciu. Efektem powodzi, które dotykały Śląsk w XVIII stuleciu, mających już miejsce $\mathrm{w}$ większości po przejściu tej krainy pod panowanie Prus, były pierwsze regulacje ustawowe, które miały tworzyć zabezpieczenie przed tego typu niebezpiecznymi zjawiskami naturalnymi. Nie były one jednak doskonałe, o czym można się było przekonać podczas kolejnych - tym razem XIX-wiecznych powodzi. Największym wstrząsem była jednak dopiero powódź z 1854 roku, która m.in. zalała prawie cały obszar miasta Wrocławia ${ }^{1}$. Zmusiła ona do podjęcia działań zaradczych, które wynikały ze skali zalanych terenów. W działaniach naprawczych postanowił wziąć udział najwyższy organ kształtującego się wówczas samorządu terytorialnego w Prusach, czyli sejm prowincjonalny (Provinziallandtag). Warto wobec tego przypomnieć najważniejsze okoliczności jego ustanowienia w XIX wieku.

1 Encyklopedia Wrocławia, red. J. Harasimowicz, Wrocław 2006, s. 709 i 710. O skali powodzi w 1854 roku zob. G. Scheuermann, Das Breslau-Lexikon, Dülmen 1994, t. II, s. 1789 i 1790. O innych powodziach zob. ibidem, t. I, s. 611-613. 
Reformy ustrojowe w Prusach, które wprowadzono po klęskach w wojnie $z$ Napoleonem I w początku XIX stulecia doprowadziły do wielu przekształceń ustrojowych. Jednym $z$ nich było otwarcie drogi do stworzenia systemu przedstawicielskiego społeczeństwa. Przejawem tych działań było m.in. powołanie w każdej z pruskich prowincji sejmu prowincjonalnego (Provinziallandtag). W 1824 roku powołano takie zgromadzenie także dla prowincji śląskiej ${ }^{2}$. Po odnowieniu tej instytucji po Wiośnie Ludów naastąpiło wiele różnych reform związanych $z$ funkcjonowaniem sejmu prowincjonalnego. Jedną $z$ tych reform było stworzenie własnej instytucji kredytowej. Jedną z nich była stanowa kasa pomocy, która zajmowała się głównie finansowaniem instytucji dobroczynnych ${ }^{3}$. Skala powodzi z 1854 roku uzmysłowiła posłom konieczność ustanowienia specjalnej instytucji kredytowej, która miałaby swój udział w finansowaniu zwalczania skutków tej ogromnej powodzi.

Powołanie stanowej prowincjonalnej kasy pożyczkowej było inicjatywą XI sejmu prowincjonalnego z $1854 \mathrm{r}$. Opracował on projekt statutu i ilość papierów wartościowych, które byłyby przedmiotem obrotu. Była to jedna $z$ najlepiej przygotowanych petycji $z$ lat 1851-1873. Zasadniczym powodem powołania kasy pożyczkowej była ciężka sytuacja gospodarcza prowincji, dla poprawy której dotychczasowe środki tymczasowe nie przynosiły rezultatu. Zdaniem posłów, konieczne stało się utworzenie nowej instytucji kredytowej, gdyż dotychczasowa kasa pomocy była niewystarczająca. Jednym $z$ głównych powodów trudnej sytuacji gospodarczej prowincji śląskiej były powodzie $z$ lat 50 . XIX stulecia, które zrujnowały gospodarkę. Sfinansowanie naprawy infrastruktury wymagało ogromnych nakładów finansowych, które można było pozyskać z kredytów o korzystnym oprocentowaniu. Takich nie gwarantował sektor bankowy, uznawano wobec tego, iż ciężar ten dla dobra ogółu mogłaby przejąć instytucja samorządowa, wsparta dotacjami rzą-

2 Pisaliśmy o tym w pracy Sejm prowincjonalny na Śląsku (1824-1933), Wrocław 2000.

3 T. Kruszewski, Ustanowienie prowincjonalnej kasy pomocy na Ślasku $w 1851$ r., Acta Universtatis Wratislaviensis, nr 2213, Prawo CCLXX, Studia Historycznoprawne, Wrocław 2000, s. 119-140. 
dowymi. Sejm prowincjonalny był w stanie wyasygnować 500 tys. talarów Rzeszy (TR) na kapitał zakładowy nowej instytucji, ale apelowano do króla i rządu pruskiego o dalsze dotacje wspierające. Od samego początku posługiwano się nazwą nowej instytucji sformułowaną na XI sejmie prowincjonalnym jako stanową prowincjonalną kasą pożyczkową i pod tą nazwą przetrwać miała ona do Machtergreifung w 1933 roku$^{4}$.

Prośby stanów kierowane do Fryderyka Wilhelma IV zmierzały do uzyskania akceptacji utworzenia kasy pożyczkowej i nadania jej statutu. Proszono króla także o wyrażenie zgody na emitowanie przez nią papierów wartościowych (obligacje na sumę $2 \mathrm{mln}$ TR). Niemniej istotna była też prośba o zgodę na ustanowienie dla kasy pożyczkowej funduszu zakładowego w wysokości 500 tys. TR $z$ budżetu prowincji oraz zwolnienia jej z opłat stemplowych. Na rozruch kasy przewidziano też pieniądze $z$ kasy pomocy, które następnie byłyby w ratach do tej kasy zwracane, w miarę jak do kasy pożyczkowej zaczęłyby wracać pieniądze od dłużników. Przewidywano też zasilanie kasy przez druk obligacji prowincjonalnych. Konieczne było powołanie także stanowej (sejmowej) komisji do kontroli poczynań kasy ${ }^{5}$.

Najważniejszym posunięciem XI landtagu było opracowanie statutu kasy z 16 października 1854 roku$^{6}$. Został on podzielony na 5 rozdziałów, które obejmowały 42 paragrafy. Rozdział I poruszał najważniejsze problemy ogólne związane $z$ celami pożyczek. Wyjaśniono przy tym, że siedziba kasy miała być we Wrocławiu. Ze środków kasy zamierzano finansować naprawę infrastruktury i zabudowań zniszczonych przez powódź, budowę wałów ochronnych, a także wsparcie dla powiatów i gmin, które chciałyby realizować inne posunięcia zabezpieczające przed powodziami.

4 Verhandlungen des elften Provinzial-Landtages des Herzogthums Schlesien, der Grafschaft Glatz und des Markgrafthums Ober-Lausitz, Preußischen Antheils, nebst von Seiner Majestät dem Könige darauf ertheilten Allerhöchsten Landtags-Abschiede vom 30. September 1856, Breslau 1856 (cyt. dalej: XI L.), t. I, s. 27-28.

5 Ibidem, s. 29.

6 Tekst statutu zob. s. 30-38, a także w ibidem, t. II jako (Drucksache) nr 30. 
W statucie znalazły się także zapisy o funduszu zakładowym w wysokości 500 tys. TR (rozdział 2, § 3). Zamierzano go utworzyć $z$ rezerw innych instytucji prowincjonalnych, m.in. zakładu dla ubogich w Kluczborku, kasy pomocy. Były to jednak środki niewystarczające, stąd pojawił się także zapis o pozyskaniu połowy wpływów $\mathrm{z}$ podatku od nieruchomości na lata 1856-1857. Podobne zapisy dotyczyły podatku klasowego i podatku od mlewa i uboju (Mahl- und Schlachtsteuer), a także podatków dochodowego i rzemieślniczego ${ }^{7}$.

Statut regulował także kwestie finansowe struktury obligacji prowincjonalnych i druków kasowych pożyczki ${ }^{8}$. Pożyczki dokonywano na procent $(4,5)$, ale $\mathrm{w}$ początkowym okresie pożyczkobiorca zwracał tylko kapitał (zwolnienie nie mogło przekroczyć 6 miesięcy). Maksymalny czas spłaty kredytu wynosić miał 15 lat ${ }^{9}$.

Rozdział III statutu regulował zasady udzielania pożyczek. Spośród wielu szczegółowych zapisów warto w tym miejscu przywołać zasadę udzielania kredytów w zasadzie tylko w gotówce (§ 17). Kredyty były udzielane od minimum 3 do maksymalnie 15 lat. Nie było opłacalne nieterminowe regulowanie rat, gdyż opóźnienia obciążano kaucją wartości 3\% kredytu.

Istotne były też przepisy o zabezpieczeniach kredytów, które w pierwszej kolejności przewidywały ustanowienie hipoteki. Dopuszczano jako zabezpieczenie także posiadanie gwarantowanych przez państwo papierów wartościowych, krajowych listów rentowych, a w ostateczności wystarczało znalezienie poręczycieli. Kwestie te dotyczyły pożyczek na naprawę nieruchomości. Inne reguły dotyczyły kredytów na naprawę lub budowę wałów przeciwpowodziowych. Te kredyty były przewidziane głównie dla powiatów i gmin. Wystąpienie o taki kredyt wymagało wcześniejszych uchwał

7 Rozdzielanie sum na Śląsk i Górne Łużyce zostało na XI sejmie prowincjonalnym zanegowane przez górnołużyckich deputowanych, zob. votum separatum w ibidem, t. I na s. 42-43.

8 Ibidem, na s. 39-41 wzory tych dokumentów.

9 Ibidem, rozdział II szczegółowo informował o wielu kwestiach technicznych, jak np. daty płatności, amortyzacja itp. 
rad tych jednostek. Kredyty były także przewidziane dla spółek wodnych (Deichverband $)^{10}$.

Jednym ze sposobów pozyskiwania środków przez kasę była emisja jej obligacji, które miały być oprocentowane 0,5\%.

Rozdział IV zawierał kwestie ustrojowe, związane $z$ odpowiedzialnością za działalność kasy. Najwyższy nadzór należał do państwa, które działało przez landtag prowincjonalny. Powiązanie kasy z nim miało istnieć poprzez dyrektorium kasy pożyczkowej. Jego skład miał być następujący: dyrektor, trzech członków (oraz ich zastępców), wybieranych spośród posłów, i syndyk kasy. Jego kadencja jego miała trwać sześć lat. Sejm miał ponadto powoływać specjalną komisję stanową, która czuwałaby nad działalnością kasy pożyczkowej. W jej skład miało wchodzić ze stanu I i IV po dwóch członków i zastępców, a ze stanu II i III odpowiednio po czterech. XI landtag od razu zaproponował królowi skład zarówno dyrektorium, jak i komisji ${ }^{11}$.

10 Rozdzielano je na podstawie wniosków takich spółek. Jako przykład można podać sprawozdanie $z 1862$ roku za rok 1860, gdzie wymieniono pożyczkobiorców - spółki: oławsko-wrocławską (25 tys. TR), domaszkowsko-małobuszkowicką (2000 TR), jurczowsko-zaborowską (5000 TR), dolnobrzeską (1000 TR) i wróblowską (2000 TR); cztery ostatnie z pow. wołowskiego. Zob. Verhandlungen des sechzehnten Provinzial-Landtages des Herzogthums Schlesien, der Grafschaft Glatz und des Markgrafthums Ober-Lausitz, Preußischen Antheils, nebst dem Allerhöchsten Landtags-Abschiede vom 28. Oktober 1863, Breslau 1863 (cyt. dalej jako XVI L.), t. II, (Drucksache) $\mathrm{nr} 21$, s. 1.

11 Skład w XI L., t. I, na s. 45-46. Dyrektorem kasy został baron Herrmann von Gaffron z Konarów (pow. zięb.). Członkami zaproponowano: przedstawiciela Ziemstwa Śląskiego hr. von Hoverden z Arnsdorf (niestety, nie wiadomo, z jakiego powiatu, stąd nie można przetłumaczyć tej nazwy), tajnego radcę handlowego Gustava Heinricha Ruffera z Wrocławia i starszego ziemskiego Eduarda Krakera von Schwarzenfeld z Bogunowa. Zastępcami zostali baron August Friedrich Karl von Schuckmann z Urazu, bankier J.A. Franck $z$ Wrocławia i posiadacz sołectwa dziedzicznego Hanke z Wojsławia (grod.). To samo w t. II jako (Drucksache) nr 46. Na każdym sejmie dokonywano kolejnych zmian w tym składzie. Po raz pierwszy nastąpiło to na XII landtagu, zob. Verhandlungen des zwölften Provinzial-Landtages des Herzogthums Schlesien, der Grafschaft Glatz und des Makgrafthums Ober-Lausitz, Preußischen Antheils, nebst dem von Sr. Königlichen 
Najważniejszy był podział zadań i odpowiedzialności między różne instytucje. Dyrektorium odpowiadało za bieżące działania kasy, jak np. udzielanie pożyczek i ustanawianie zabezpieczeń. Nadzór wyższy należał do komisji stanów prowincjonalnych. Miała ona powoływać syndyka kasy i innych urzędników, odpowiedzialnych za kontrolowanie, czy dług jest spłacany. Ustalała ona także zasady ich wynagradzania. Do jej zadań należało ustalanie stóp procentowych kredytów i obligacji kasy dla wszystkich klientów, w tym także dla spółek wodnych. Regulowała także kwestie nadzoru nad nierzetelnymi dłużnikami ${ }^{12}$.

Ostatni rozdział przewidywał ścisłe powiązanie samorządów powiatowych i gminnych $z$ kasą. Miały one powoływać lokalne komisje dla współpracy $\mathrm{z}$ kasą na ich obszarze działania.

W recesie XI sejmu prowincjonalnego z 30 września 1856 r. król Fryderyk Wilhelm IV podzielił petycję XI sejmu, wyjaśniając, że 5 grudnia 1854 r. powołał do życia prowincjonalną kasę pożyczkową (Ständische Provinzial-Darlehns-Kasse) i wyposażył ją w proponowany kapitał zakładowy ${ }^{13}$.

Natomiast w dekrecie propozycyjnym na XIII landtag z 28 listopada 1858 r. regent Wilhelm (sprawujący władzę od chwili, gdy choroba umysłowa całkowicie zmąciła umysł jego brata Fryderyka Wilhelma IV) zaproponował, by zasadnicze środki $z$ kasy przeznaczyć na pożyczki dla spółek wodnych ${ }^{14}$. Do tej propozycji odniósł

Hoheit dem Prinzen von Preussen Regenten darauf ertheilten Allerhöchsten Landtags-Abschiede vom achtundzwanzigsten November 1858, Breslau 1858 (cyt. dalej: XII L.), t. II, (Drucksache) nr 40.

12 Wiele regulacji związanych $\mathrm{z}$ różnymi zabezpieczeniami kredytów.

13 XI L, s. 102, Statut ogłoszono 5 XII 1854 r., opublikowany został w Gesetzsammlung für die Königlichen Preußischen Staaten (cyt. dalej PGS), Jg. 1854, s. 609, nr 4123, Allerhöchster Erlaß vom 5. Dezember 1854, betreffend die Genehmigung der Statuten der ständischen Darlehnskasse für die Provinz Schlesien. Wszedł on w życie 8 I 1855 r. Dołączono te same załączniki, których projekt jest w aktach landtagu. Od s. 621 są Schema I zu den Schlesischen Provinzial-Obligationen, Schema zu Zinskupons von Provinzial-Obligationen i Schema II zu den Schlesischen Provinzial-Darlehne-Kassenscheinen.

14 Verhandlungen des dreizehnten Provinzial-Landtages des Herzogthums Schlesien, der Grafschaft Glatz und des Markgrafthums Oberlausitz, Preu- 
się sejm prowincjonalny w opinii z 22 grudnia tegoż roku. Zwrócono uwagę, że zwalczanie skutków powodzi w 1854 r. wymagało znacznie większych środków, niż się to wcześniej wydawało. Na ten cel do końca 1857 r. wyasygnowano 1066000 TR (w rejencji wrocławskiej 525 tys., opolskiej 125 tys. i w legnickiej 416 tys.). Prace przy regulacji Odry, zmierzające do zmniejszania ryzyka powodzi, wymagały intensywnych prac ziemnych, które $z$ kolei wymagały ogromnych środków, dlatego też prócz samych pożyczek konieczne były dogodne terminy amortyzacji odsetek. $Z$ powodu ogromnych kłopotów płatniczych uznano za konieczne wydłużyć terminy maksymalnej długości zwrotu pożyczek z 15 lat o kolejne 12 lat dla członków spółek wodnych. Stanowisko to nie zostało przyjęte jednogłośnie, gdyż votum separatum zgłosili posłowie z Górnych Łużyc (także z 22 grudnia 1858 r.). Ci bowiem domagali się zagwarantowania im odrębnej puli pieniędzy $z$ nadwyżki ściągniętych odsetek po upływie dotychczasowego terminu maksymalnego kredytowania (czyli po 15 latach). Uważali, że ta część prowincji była gorzej traktowana przez Śląsk ${ }^{15}$. Ze stanowiskiem stanów prowincjonalnych zgodził się regent Wilhelm w recesie z 15 października 1860 r. Nie poparł natomiast stanowiska posłów górnołużyckich, gdyż jego zdaniem nie było zgodne $z$ ustawą o sejmie prowincjonalnym z 27 marca 1824 r., która takie kompetencje dawała tylko stanom prowincjonalnym ${ }^{16}$. Omówione zmiany weszły w życie 28 marca 1859 r., dalsze ogłoszono 3 kwietnia 1865 r. ${ }^{17}$

Bischen Antheils, nebst dem von Sr. Königlichen Hoheit dem Prinzen von Preussen, Regenten, darauf ertheilten Allerhöchsten Landtags-Abschiede vom 15. Oktober 1860, Breslau 1860 (cyt. dalej: XIII L.), s. 1.

15 XIII L., s. 14 i 15 . Odrębne stanowisko w tej sprawie zgłosiło 11 posłów górnołużyckich (votum separatum z 22 XII 1858 r.), s. 16 i 17. Zob. też (Drucksache) nr 14 Entwurf eines Nachtrags zu den Statuten der ständischen Darlehnskasse für die Provinz Schlesien. Stanowisko komisji III sejmu prowincjonalnego stanowi (Drucksache) nr 35 z 18 XII 1858 r.

16 XIII L., S. 57.

17 PGS, Jg. 1859, s. 213, nr 5055, Allerhöchster Erlaß vom 28. März 1859, betreffend die Genehmigung eines Nachtrags zu dem Statuten der ständischen Darlehnskasse für Schlesien, in Bezug auf die Erweiterung der Rückzahlungsfrist für Darlehne an Deichgenossen; Jg. 1865, s. 270. 
Oprócz pożyczek stałym elementem sprawozdawczości był etat kasy, który obejmował sumy bezpośrednio związane $z$ jej działalnością (np. kancelaryjne). Począwszy od XII sejmu prowincjonalnego, każdemu sejmowi przedstawiano sprawozdania finansowe z działalności kasy. Podnosiły one kwestie personalne, informując o zmianach członków instytucji związanych $z$ kasą, ale przede wszystkim szczegółowo odnosiły się do kwestii finansowych. Dla zorientowania $\mathrm{w}$ tej sprawozdawczości warto zwrócić uwagę, że podawano m.in. liczbę osób, które otrzymywały pożyczki. I tak np. w aktach XII landtagu (1856 r.) wyjaśniono, że udzielono 93 pożyczek posiadaczom dóbr rycerskich, 32 dzierżawcom, 178 posiadaczom gruntów miejskich i 1875 posiadaczom gruntów wiejskich. Większą część sprawozdań przeznaczano na szczegółowe rozliczenia finansowe. I tak np. spółki wodne otrzymały znaczące sumy pieniędzy na budowę wałów przeciwpowodziowych. W rejencji wrocławskiej było to 432 tys. TR, w legnickiej 342 tys. i w opolskiej 126 tys. ${ }^{18}$ Podobnie było na kolejnym XIII landtagu, gdzie rozliczano lata 1856-1857 ${ }^{19}$. Udzielono wtedy pożyczek na sumę 1999902 TR, z których większość (1 813902 TR) poszła na pożyczki dla osób prywatnych. Sprawozdanie omawiało także liczbę spółek wodnych z poszczególnych powiatów, które otrzymały wsparcie. Rozliczono również koszty administracyjne. Jednym z zadań XIII sejmu prowincjonalnego stało się także opracowanie budżetu administracyjnego kasy na 1859 r. Do tego sprawozdania dołączono również sprawozdanie dyrektorium kasy, które w dość szczegółowy sposób odnosiło się do pożyczek i wydatków kasy ${ }^{20}$. Globalne kwestie tych rozliczeń przedstawia tabela 1 , w której wyszczególniono dane $z$ wybranych sejmów prowincjonalnych.

18 XII L., t. II (Drucksache) nr 39 (referat komisji III z 20 X 1856 r.).

19 XIII L., (Drucksache) nr 19 (referat komisji z 13 XII 1858 r.).

20 XIII L., Zu nr 19, Geschäfts-Bericht des Direktorii der ständischen Provinzial-Darlehnskasse für Schlesien pro 1856, Breslau, den 18. Mai 1857. Dalej jest identyczne sprawozdanie za 1857 rok z 12 IV 1858 r. Stanowisko komisji III sejmu prowincjonalnego zalecające przyjęcie tych sprawozdań zawarto w (Drucksache) nr 40 z 20 XII 1858 r. 
Od XIV sejmu wykształciła się pełna sprawozdawczość kasy, która w niezmienionej postaci przetrwała do $1925 \mathrm{r} .{ }^{21}$ Obejmowała ona charakterystykę pożyczek ${ }^{22}$, zamknięcie rachunków, zwrot pożyczek i odsetek, obligacje prowincjonalne, kwity kasy, niszczenie pokwitowań zwróconych kredytów i stopę oprocentowania pożyczek. Kasa mogła udzielać pożyczek gotówkowych (oprocentowanie ustalono na 4,5\%) w papierach wartościowych oraz lombardowych, mogła też wypuszczać własne obligacje. Podstawą finansową kasy był rosnący $z$ roku na rok kapitał zakładowy. Sporządzano sprawozdania za dwa kolejne lata ze względu na zwoływanie sejmu prowincjonalnego. Były one przygotowywane przez dyrektorium kasy. Dołączano także stanowisko sejmowej komisji, które odnosiło się do tych sprawozdań, było ono pomocą dla posłów w ocenie sytuacji kasy. Zadaniem kasy było także ustalanie budżetu kasy na dwa kolejne lata oraz zgłaszanie propozycji w zmianach składu dyrektorium i komisji kontrolującej kasę. $Z$ landtagu na landtag sprawozdania stawały się dokładniejsze i bardziej szczegółowe ${ }^{23}$.

21 Verhandlungen des vierzehnten Provinzial-Landtages des Herzogthums Schlesien, der Grafschaft Glatz und des Markgrafthums Oberlausitz, PreuBischen Antheils, nebst dem Allerhöchsten Landtags-Abschiede vom 15. November 1862, Breslau 1862 (cyt. dalej jako XIV L.), (Drucksache) nr 19, 20-23, 36 i 37. Podobnie dalej zob. XVI L., t. II, (Drucksache) nr 20-23 i 44; XVIII L., t. II, (Drucksache) nr 3, 4, 41, 42 i 45.

22 Podawano zawsze wykaz spółek wodnych oraz indywidualnych pożyczkobiorców wraz z sumami pieniędzy.

23 Por. Verhandlungen des 18. und 19. Provinzial-Landtages des Herzogthums Schlesien, der Grafschaft Glatz und des Markgrafthums Ober-Lausitz, Preußischen Antheils, nebst dem Allerhöchsten Landtags-Abschiede vom 11. März 1868, Breslau 1868 (obejmuje dwa landtagi, ale wspólny jest tylko tytuł i oprawa, odrębna paginacja) oraz tom bez tytułu i daty wydania (może pochodzić nawet z 1864 r.), zawierający akta sejmowe. Ten jest cyt. jako XVIII L., t. II, (Drucksache) nr 3 i 4. Dalsze sprawozdania posiadały jeszcze bardziej skomplikowane struktury wewnętrzne, por. Verhandlungen des 20. und 21. Provinzial-Landtages des Herzogthums Schlesien, der Grafschaft Glatz und des Markgrafthums Ober-Lausitz, Preußischen Antheils, Breslau 1869 (dwa tomy wspólnie oprawione, wspólny tylko tytuł, gdyż mają odrębną paginację). Istnieje także nie oznaczony tytułem tom akt sejmowych, zapewne z 1868 r. Ten ostatni cyt. jako XX L, t. II, (Drucksache) nr 16 z ogromną liczbą załączników. 
Dla zobrazowania, jak skomplikowane dokumenty tworzono na użytek sprawozdawczości kasy pożyczkowej, posłużymy się dokumentami opracowanymi na potrzeby XVIII sejmu prowincjonalnego w 1864 roku. Najważniejsze informacje gromadzono w sprawozdaniach dyrektorium kasy za dany rok. Umieszczano w nich informacje w stałym porządku. Otwierały je dane o nowych pożyczkach. Nie zawsze zawierały one określoną zawartość, zwłaszcza gdy nie udzielano nowych kredytów. Kasa pożyczkowa nie prowadziła bowiem regularnej działalności kredytowej - pożyczki dawała tylko w razie powodzi, udzielała także kredytów dla spółek wodnych, ale były to działania długoterminowe i po wykorzystaniu większej puli kredytów nie udzielała nowych do czasu zrealizowania aktualnych inwestycji. Tak było właśnie na XVIII landtagu ${ }^{24}$. Kolejną częścią sprawozdań były rozliczenia finansowe, związane $\mathrm{z}$ zamknięciem rachunków za dany rok. Informowano zwłaszcza o stanie kasy, były to duże środki jak na ówczesne czasy. I tak na koniec roku 1862 roku zgromadzono 608178 TR, 23 sr gr i 10 fen. W porównaniu z rokiem poprzednim zasoby kasy wzrosły o 26015 TR, 21 sr gr i 3 fen ${ }^{25}$.

Rozliczano także odsetki na rachunkach bankowych kasy. W skali wieloletniej były to duże sumy. Po ośmiu latach istnienia kasy w 1862 roku odsetki przekraczały 90 tys. TR, choć w skali jednego roku nie zawsze wzrost był wysoki (w 1862 roku sięgnął nieco ponad $85 \mathrm{TR})^{26}$. Znacznie większe zyski osiągano na obrocie papierami wartościowymi - w 1862 roku pozyskano ponad 1216 TR.

Zyski osiągano również $\mathrm{z}$ obrotu prowincjonalnymi obligacjami. Informacje $z 1862$ roku pokazują jednak, że były to, $z$ racji wahań kursów, dość niestabilne dochody. Zawsze jednak przynosiły pewne $z_{y s k i}{ }^{27}$. Ważne są informacje o globalnym majątku kasy pożyczkowej, który był znaczny (zob. informacje zawarte w tabeli 2).

Część wydatków kasy miało stały charakter. Zaliczano do nich koszty zarządu, które obejmowały: diety członków stanowej komisji,

24 XVIII L., t. II, op.cit.

25 Ibidem, (Drucksache) nr 3, s. 2. Na s. 6-10 zawarto informacje, na co wydano te nadwyżki.

${ }^{26}$ Ibidem, (Drucksache) nr 3, s. 3.

27 Ibidem, (Drucksache) nr 3, s. 13-16. 
członków dyrektorium, pracowników pomocniczych, wydatki administracyjne, wypłaty $z$ funduszu dyspozycyjnego i tantiemy poborców podatkowych, bo to oni właśnie ściągali raty kredytów od pożyczkobiorców. Wydatki te w 1862 roku wyniosły ponad 1105 TR. Skwapliwie informowano także o niedoborach - dotyczyło to dłużników, którzy nie wywiązywali się z rzetelnego spłacania rat. W każdym sprawozdaniu były to imienne informacje o każdym dłużniku i wysokości długu ${ }^{28}$. Informacje o kredytach zajmowały zawsze znaczącą część sprawozdań. Obok informacji o wysokości spłacanych kredytów umieszczano także imienne dane o dłużnikach, którzy popadli w kłopoty finansowe, którym wobec tego udzielano odroczeń na spłaty lub zmniejszano ich wysokość. Uporczywe niespłacanie długów w ekstremalnych wypadkach prowadziło do przymusowych licytacji majątku dłużników - nie były to przypadki rzadkie ${ }^{29}$.

$Z$ racji dużych trudności w odzyskiwaniu pożyczonych sum XVIII sejm skierował petycję do Wilhelma I o przedłużenie terminu amortyzacji kredytów i odsetek, gdyż w czasie recesji wielu dłużników nie było w stanie spłacać długów w terminie. Na XVIII sejmie prowincjonalnym przypomniano także uchwałę XVI sejmu o utworzeniu dodatkowego funduszu 250 tys. TR, z którego można było pożyczać na $4 \%$ z okresem płatności do 1887 roku. Dyrektorium kasy proponowało tworzenie dalszych funduszy, które mogłyby wspierać zwalczanie skutków powodzi z 1854 r., gdyż - jak ustalono w 1862 r. - ciągle jeszcze nie naprawiono wszystkich szkód. Doszło też do wydzielenia $z$ kasy pożyczkowej części aktywów na utworzenie odrębnej kasy dla Górnych Łużyc. W recesie końcowym (wspólnym dla XVIII i XIX sejmu) król poparł stanowisko posłów w tych kwestiach ${ }^{30}$. Poprawki te znalazły następnie odbicie w rozkazie królewskim z 3 kwietnia 1865 roku, który dotyczył dwóch zmian

28 Ibidem, (Drucksache) nr 3, s. 4 i 5.

29 Ibidem, (Drucksache) nr 3, s. 12 i 13. W 1862 roku zlicytowano 27 majątków. Niektórzy ratowali się przed licytacją odstępując samorządowi prowincjonalnemu część swoich gruntów.

30 XVIII L., t. I, s. 30 i 31; zob. także XIX landtag, który ma t. I wspólnie oprawiony z XVIII L., (po s. 48), oprócz tego Plenar-Verhandlungen des XIX. (ausserordentlichen) Provinzial-Landtages, Breslau, br. daty (1866 ?); tutaj ta druga połowa tomu wspólnego będzie cytowana jako XIX L., t. I, s. 27. 
w statucie kasy. Pierwsza dotyczyła mienia kasy, wobec którego komunalny landtag Górnych Łużyc mógł rozporządzić, że stosownie do udziału Górnych Łużyc w funduszu zakładowym według stanu rachunków na dzień 31 grudnia 1864 roku ustalona według nich suma pieniędzy mogła być przez Górne Łużyce wypłacana gotówką do dnia 1 lipca 1867 roku. Obowiązywała w tym miejscu zasada, że ustalona suma pieniędzy mogła być wypłacana począwszy od 1 stycznia 1865 roku, wraz z odsetkami, które ustalono na 4\%. Druga poprawka miała podobny charakter do poprawki z 1859 roku - dla spółek wodnych termin amortyzacji pożyczek został przedłużony o kolejne 8 lat, ale ten nowy termin nie mógł jednak przekroczyć 1891 roku (w wyjątkowych wypadkach 1894 roku) ${ }^{31}$.

Nie można pominąć w tym miejscu działań sejmu prowincjonalnego związanych $z$ regulacją Odry. Posłowie wychodzili ze słusznego założenia, że tylko działania $\mathrm{w}$ państwie związane $\mathrm{z}$ zabezpieczaniem terenów od zalania dadzą najlepsze efekty. Petycję o podjęcie regulacji głównej rzeki Śląska zgłosił do króla Wilhelma I XVI sejm prowincjonalny (petycja $z 4$ grudnia 1862 roku) ${ }^{32}$. Przypomniano w niej, że rząd pruski dostrzegł już problem regulacji Odry i 24 stycznia 1862 roku powołał Komitet Zrzeszenia Odry, ale działania - zdaniem posłów - należało bardziej zintensyfikować. Podkreślali, że tylko działania regulacyjne na całej długości biegu rzeki mogły przynieść poprawę sytuacji. Stąd widzieli konieczność koordynacji prac na obszarze prowincji śląskiej, brandenburskiej i pomorskiej. Prace wymagały jednak ogromnych środków finansowych, dlatego wyrażono prośbę o pozyskanie środków rządowych, gdyż prywatne pożyczki były niewystarczające.

Wilhelm I w recesie końcowym z 28 października 1863 roku ustosunkował się do tych próśb, zapowiadając przyśpieszenie prac nad regulacją Odry. Przypomniał, że w latach 1859-1862 wydano 579500 TR na prace związane $z$ regulacją biegu Odry, w kolejnym roku, 1863, do daty ogłoszenia recesu poszło na te cele 214500

31 PGS, Jg. 1865, s. 270, nr 6063, Allerhöchster Erlaß vom 3. April 1865, betreffend zwei Abänderungen der Statuten der ständischen Darlehnskasse für die Provinz Schlesien.

32 XVI L., t. I, s. 36 i 37. 
TR. Zapowiedział ze skarbu państwa dalsze wydatki, choć nie określił ich wysokości ${ }^{33}$.

XX landtag obradujący w 1868 roku poświęcił omawianiu sytuacji kasy pożyczkowej dużo miejsca. Wiązało się to z planowanymi zmianami w statucie i opracowaniem projektu regulaminu kasy, która dotychczas pracowała według cząstkowych regulacji. Zmiany $\mathrm{w}$ statucie związane były w nowymi regulacjami dotyczącymi pożyczek hipotecznych ${ }^{34}$. Jedną $z$ istotnych kwestii, które podniesiono na XX landtagu, była niedostateczność środków, którymi dysponowała kasa na zwalczanie skutków powodzi. Ustalony w 1854 roku kapitał zakładowy na sumę 500 tys. TR nie zaspokajał potrzeb i powodował ubóstwo środków przeciwpowodziowych. Domagano się zwiększenia kapitału przynajmniej o tyle, by można było udzielać pożyczek na sumy 700 lub 800 tys. TR. Ostatecznie XX sejm ustalił ją na poziomie 992025 TR na koniec $1866 \mathrm{r}$.

Posłowie widzieli konieczność dalszego istnienia kasy, ale podzielenia jej środków na Śląsk i Górne Łużyce nie uznawali za rzecz korzystną, z racji rozdrabniania środków. Dystrybucja powinna iść przez organy prowincjonalne, które widziały problemy globalnie. Dotychczasowa dystrybucja przez powiaty utrudniała - zdaniem posłów - cele ogólne. Zwalczanie skutków powodzi musiało być związane ze wskazywaniem innych dalszych celów związanych z bezpieczeństwem przeciwpowodziowym. Dla zwiększenia kapitału kasy uznano konieczność emisji kolejnej tury obligacji prowincjonalnych na sumę 1,5 mln TR. Na to jednak trzeba uzyskać zgodę państwa pruskiego. Te zmiany prowadziły do głębszej rewizji przepisów administracyjnych kasy ${ }^{35}$. Konsekwencją tych propozycji były

33 Ibidem, s. 63.

34 XX L., t. II (Drucksache) nr 15 (sprawozdanie komisji stanowej i dyrektorium kasy z 17 III 1868 r.; projekt zmian w statucie i projekt regulaminu; w nr 16.2.d zawarto regulatyw pożyczek hipotecznych z 6 XII 1865 r., nr 26 i 29.

35 Kwestie te zawierało stanowisko stanowej komisji z 17 III 1868 r. Zob. (Drucksache) nr 15, Bericht betreffend die fernere Verwendung des Vermögens auf dem Beschluß des XVIII. Provinzial-Landtages vom 18. Oktober 1864. Stanowisko to poparła komisja stanowa kasy, zob. (Drucksache) nr 15a. 
zmiany w statucie kasy, które ogłoszono na XX sejmie prowincjonalnym. Zmierzały one do podwyższenia kapitału zakładowego kasy do 1,5 mln TR, zwiększenia obligacji prowincjonalnych dla realizacji tego celu (druk obligacji o oprocentowaniu 4 lub 4,5\%). Poszerzono znacznie katalog szkód powodziowych, który uzasadniał starania o pożyczki. Dopisano wspieranie posiadaczy gruntowych, którzy wskutek powodzi ponieśli szczególne szkody, oddzielnie wyliczono tu straty w inwentarzu i mieniu gospodarczym. Doszły do tego wydatki na meliorację gruntów, które miały ulepszyć sytuację nawodnienia i odwodnienia nieruchomości. Ustalenie wysokości oprocentowania tych nowych pożyczek pozostawiono w gestii sejmu prowincjonalnego.

Gromadzenie środków było w dalszym ciągu zadaniem dyrektorium kasy, ale poszerzono na XX landtagu możliwości ich pozyskiwania. Można było tworzyć spółki komandytowe wraz z bankiem państwowym. Rezerwy mogły pochodzić z zakupu przedmiotów wartościowych i papierów wartościowych. Wprowadzono nową formę kredytów pod zastaw papierów wartościowych (zwanych również lombardowymi), a także kredyty hipoteczne. Te ostatnie wymagały jednak zezwolenia nadprezydenta prowincji (§ 83 tyt. 6 cz. II ALR).

Do dyrektorium kasy musiał zostać wprowadzony przedstawiciel kupców, który pochodził z Wrocławia. Nie musiał być posłem, stąd jego wybór oznaczał poszerzenie dyrektorium o następną osobę. Uzyskiwał pełne prawa członka dyrektorium. Tego ostatniego nie musiał już wyłącznie zwoływać dyrektor, mogło się ono także zebrać na wniosek dwóch członków. Ważne były też uregulowania dotyczące podpisów na dokumentach pożyczkowych - mogły je składać tylko osoby upoważnione do czynności kasowych. Czynności związane $z$ potwierdzaniem stanu kasy, ruchem pieniężnym i stanem kredytów lombardowych wymagały każdorazowo sprawdzenia wyższych urzędników ${ }^{36}$.

Ogłoszono także regulamin samego dyrektorium kasy. Jego rozdział I odwoływał się do zasad ustanawiania dyrektorium, które

36 Tekst dodatku do statutu kasy w (Drucksache) nr 15a, s. 4-7. Uzasadnienie do projektu na s. 17-23. 
miało być kolegium w rozumieniu §§ 114, 115, 119-121 tyt. 10 cz. II ALR. Jednym $z$ najważniejszym zadań dyrektorium było zatwierdzanie pożyczek, których rodzaje wymieniono: kredyty hipoteczne dla korporacji prawa publicznego, gmin i spółek wodnych, lombardowe (pod zastaw) i zwykłe.

Dla kontroli kasowej ustanowiono specjalnego urzędnika, który musiał mieć wykształcenie kupieckie. Nosił on tytuł syndyka kasy. Zatwierdzanie pożyczek wymagało kolegialnej decyzji dyrektorium.

Rozdział II statutu dotyczył funduszy i kapitału zakładowego. Nie wprowadzono tu większych zmian do dotychczasowych uregulowań. Były to zarówno to środki finansowe, jak i papiery wartościowe. Szczególne znaczenie miały w dalszym ciągu obligacje prowincjonalne. Najważniejszy był przedostatni rozdział, który dzielił się na pięć punktów. Były to szczegółowe zasady działań finansowych kasy. Punkt 2 poruszał zasady udzielania kredytów. $Z$ tych regulacji można wspomnieć przepisy o sprawdzaniu wiarygodności pożyczkobiorców, co wynikało m.in. $z$ długiego okresu udzielania kredytów (24 lata). Wysokość udzielanych kredytów za każdym razem była zastrzeżona dla dyrektorium. Odrębne regulacje dotyczyły różnych rodzajów kredytów. Dużo miejsce poświecono pożyczkom hipotecznym. Były to nowoczesne uregulowania dotyczące warunków udzielania kredytów czy np. sprawdzania zabezpieczenia. Przepisy o ustalaniu wartości nieruchomości było precyzyjne, odwoływały się do pruskiej ustawy o podatku o nieruchomości z 21 maja $1861 \mathrm{roku}^{37}$. Dopuszczono możliwość braku spłaty kredytu od razu po jego uzyskaniu, ale takie odroczenie płatności nie mogło trwać więcej niż trzy lata.

Odrębnie uregulowano w statucie pożyczki na ulepszenie kultury rolnej. Tutaj także dopuszczano możliwość kredytów hipotecznych, ale przewidywano również pożyczki oparte na gwarantowanych przez państwo listach rentowych i innych papierach wartościowych. Ostatni rodzaj stanowiły pożyczki $z$ udziałem poręczycieli. Kredyty $z$ tej puli udzielano na okres od 15 do 24 lat.

37 PGS, s. 253 i n. nr 5379, Gesetz, betreffend die anderweite Regelung der Grundsteuer. Vom 21. Mai 1861. 
Amortyzacja kredytów hipotecznych uwzględniała w 2/3 wysokość czystych dochodów $\mathrm{z}$ gospodarstwa rolnego, w pozostałej $1 / 3$ aktualnej wartości nieruchomości. Kredyty oparte na zastawieniu tylko gruntów rolnych amortyzację liczyły jedynie na wartości tych gruntów. Inaczej liczono ostatni rodzaj pożyczek lombardowych. Obejmowały one w zasadzie wyłącznie zastaw papierów wartościowych i przedmiotów znacznej wartości. Zasady obliczania ich wartości ustalał bank państwa. W razie potrzeby można było uwzględniać te pożyczki jako dodatkowy zapis przy kredycie hipotecznym.

Z przepisów ostatniego rozdziału IV statutu warto zwrócić uwagę na zapis, że nie działa on wstecz i nie dotyczy kredytów udzielonych przed jego wejściem w życie ${ }^{38}$.

Podniesione tu uregulowania miały znaczenie dla przyszłego funkcjonowania kasy. Szukano także tymczasowych uregulowań dla najbliższej przyszłości, które miały pomóc w szybkim załagodzeniu braku środków. Tych tymczasowo szukano w nadwyżkach innych funduszy prowincjonalnych ${ }^{39}$.

Dla funkcjonowania kasy istotne znaczenie miały także zaproponowane na XX sejmie prowincjonalnym zmiany ustawowe. Ważna dla porządkowania rzek była fryderycjańska ordynacja z 12 września 1763 roku o struży i pilnowaniu nabrzeży (Ufer-, Ward- und Hegungsordnung). Przepisy 200 lat od ich ogłoszenia były już zupełnie przestarzałe i nie zabezpieczały ludzi przed powodziami, stąd XX landtagu zgłosił konieczne jej zmiany. W obszernym memoriale dla Wilhelma I posłowie przypomnieli najbardziej przestarzałe uregulowania związane $z$ oczyszczaniem rzek $z$ drzew i innych pływających obiektów. Wskazali, że już w dawniejszych latach padały

38 XX L., t. I, (Drucksache) nr 15a, s. 8-16. Uzasadnienie do projektu na s. 24-27.

39 Ibidem, (Drucksache) nr 15b. Referat über die von dem Directorium der ständischen Darlehnskasse der ständischen Commission zur Prüfung und Beschlussfassung untergestellten Vorschläge für die künftige Verwendung des Vermögens der ständischen Darlehnskasse. Dodano także stanowisko nadprezydenta prowincji hr. Roberta von Zedlitz-Trützschlera. W tym ostatnim dokumencie na s. 7 zawarto wysokość poborów urzędników kasy. 
postulaty ulepszania ordynacji. Istotna była nowelizacja ustawy z 25 czerwca 1855 roku $^{40}$. Zawierała ona ważne regulacje dotyczące odpowiedzialności posiadaczy nabrzeży w wypadku udowodnionej szkody z tytułu uszkodzonych brzegów. Posiadacze mieli odpowiadać za uszkodzenia nabrzeży tylko w wypadku dużego i średniego stopnia zawinienia.

Uważano jednak, że nowelizacja nie dokonała zmian w innych zdaniem posłów - błędnych uregulowaniach. W memoriale wskazano np. na przepis, który w całości koszty naprawiania nabrzeża zrzucał na właściciela brzegu - zdaniem posłów powinien on liczyć na wsparcie państwa, zwłaszcza że w innych pruskich prowincjach było takie wsparcie ze strony państwa.

Posłowie XX sejmu prowincjonalnego nie widzieli już żadnych możliwości ulepszania tej ordynacji. Za główną jej wadę uważali partykularyzm. Ordynacja dotyczyła tylko Śląska, ich zdaniem teraz należało uchwalić w pruskim landtagu ustawę ogólnokrajową. Jako środek tymczasowy widzieli możliwość zastosowania $§ 79$ tyt. $15 \mathrm{cz}$. II landrechtu pruskiego, który dla głównych rzek przewidywał ich czyszczenie na koszt państwa, by bieg był żeglowny. Ustawa nowelizująca z 25 czerwca 1855 roku była na tyle niejasna, że kierowała się na odpowiedzialność policyjną i środki dowodowe były skonstruowane niedokładnie, co utrudniało dochodzenie roszczeń. W tych okolicznościach XX landtagu zgłosił konieczność głębokich zmian ustawowych ${ }^{41}$.

Na XXI nadzwyczajnym sejmie w 1869 roku nastąpiło przejęcie zarządu nad kasą przez Krajową Deputację Prowincji Śląskiej (LDPS). Deputacja przejęła jednak tylko sprawy najważniejsze (zarząd majątkiem kasy, ściąganie pożyczek i dyspozycja kwitami kasy). Sprawy bieżącego zarządu zachowało dyrektorium w składzie: dyrektor, trzech posłów i syndyk krajowy (ale ten bez prawa głosu). Według dotychczasowych przepisów nadzór państwowy nad

40 PGS, s. 517. nr 4256, Gesetz wegen Deklaration der Artikel III. und IV. der Ufer-, Ward- und Hegungsordnung für das Herzogthum Schlesien und die Grafschaft Glatz vom 12. September 1763. Vom 25. Juni 1855.

41 XX L., t. I, s. 35, Petycja z 30 III 1868 r., memoriał s. 36-40. 
kasą sprawował nadprezydent jako komisarz sejmu. W związku $z$ usamodzielnieniem finansowym landtagu przepis ten na XXI sejmie zmieniono i w tej sytuacji - zdaniem posłów - nie była potrzebna prosta zamiana: nadprezydent - kierownik kasy głównej. Sugerowano zmianę statutu tak, by połączyć nadzór z kierownictwem i by dyrektor kasy głównej był zarazem dyrektorem kasy pożyczkowej. Ostatecznie zwyciężył pogląd, że dyrektorem winien zostać starosta krajowy. Zlikwidowana miała być natomiast stanowa komisja sejmu, która nadzorowała dyrektorium, w jej miejsce weszła bowiem deputacja krajowa ${ }^{42}$.

W pierwszych miesiącach po ustanowieniu II Rzeszy Niemieckiej latem 1871 roku XXII sejm prowincjonalny, mając rozstrzygnięte kwestie ustrojowe, ograniczył się już tylko do zbadania ówczesnego stanu kapitału zakładowego kasy, który na koniec 1870 r. wynosił $853357 \mathrm{TR}^{43}$. Dokonano ponownego wyboru dyrektorium; dyrektorem pozostał nadal Eduard Kraker von Schwarzenfeld, członkami zaś tajny radca handlowy Franck $z$ Wrocławia, radca rejencyjny w st. spocz. Remus von Woyrsch $z$ Wrocławia-Pilczyc i radca urzędowy Karl von Rother $\mathrm{z}$ Rogowa Legnickiego. Syndykiem pozostawał początkowo Koch, ale powołano go do pruskiego Ministerstwa Finansów i zastąpił go wyższy radca rządowy Brenning. Po ustąpieniu Brenninga nowym syndykiem krajowym został Marcinowski. W chwili powołania starosty krajowego został on $z$ mocy prawa dyrektorem kasy, stąd Eduard Kraker von Schwarzenfeld ustąpił ze stanowiska i zastąpił go starosta krajowy Karl von Pückler-Burghauß.

42 XXI landtag jest wspólnie oprawiony z XX (po s. 65). Oprócz tego Plenar-Verhandlungen des XXI. (ausserordentlichen) Provinzial-Landtages, Breslau, br. daty (1870 ?). Ten ostatni cyt. jako XXI L., t. II, (Drucksache) (przed nr 1), s. 5 i 6 oraz nr 5 (memoriał ministrów finansów i spraw wewnętrznych).

43 Plenar-Verhandlungen des XXII. Provinzial-Landtages des Herzogthums Schlesien, der Grafschaft Glatz und des Markgrafthums Ober-Lausitz vom 20. Juni bis einschließlich den 6. Juli 1871, Breslau, br. daty (1871 ?), cyt. dalej jako XXII L., Abtheilung C.I, s. 3; C.VI (sprawozdania z działalności kasy $\mathrm{z}$ lat 1868-1870). 
XXI sejm prowincjonalny oceniał także sytuację finansową kasy pożyczkowej za lata 1868-1870. W podanym okresie udzielono pożyczek na sumę 886713 TR i 15 sr gr, z czego najwięcej, bo 747661 TR otrzymały spółki wodne, reszta przypadła powiatom i gminom (66 $020 \mathrm{TR}$ ) oraz osobom prywatnym (73 $032 \mathrm{TR}$ i $15 \mathrm{sr}$ gr) ${ }^{44}$.

XXIII sejm zakończył długotrwały okres tworzenia zasad funkcjonowania stanowej prowincjonalnej kasy pożyczkowej. Rola sejmu wobec tej instytucji była ograniczona, gdyż kasa $z$ natury rzeczy musiała charakteryzować się autonomią. Sejm mógł jedynie wyznaczać kasie ogólne ramy funkcjonowania przez przekazywanie jej określonych sum na pożyczki i zatwierdzać stan kasy według sum, jakie przyjmowano na każdym sejmie ${ }^{45}$. Pogłębiła się w tym okresie dysproporcja między pożyczkami dla spółek wodnych i osób prywatnych. I tak np. na rok 1871 była to dysproporcja drastyczna (spółki otrzymały kredyty na 670609 TR, a osoby prywatne tylko $625 \mathrm{TR})^{46}$. Utrzymała się ona także w następnym roku (sumy odpowiednio 612807 TR i 615 TR) ${ }^{47}$. Wysokość sum będących na stanie kasy oraz wartości gotówki i papierów wartościowych ilustrują tabele 1 i 2 .

\footnotetext{
44 XXII L., Abtheilung C.VI (sprawozdania z działalności kasy z lat 1868$-1870)$.

45 Plenar-Verhandlungen des XXII. Provinzial-Landtages des Herzogthums Schlesien, der Grafschaft Glatz und des Markgrafthums Ober-Lausitz vom 20. Juni bis einschließlich den 6. Juli 1871, Breslau, br. daty (1871 ?), cyt. dalej jako XXIII L., Drucksachen nr 1, s. 36 i 37, oraz Anlage C do s. 36, Drucksachen nr 2, s. 142 i załącznik Anlage D do s. 142. nr 21 (budżet kasy na rok 1873), nr 42 (zatwierdzenie stanu finansowego kasy).

46 XXIII L., Drucksachen nr 1, s. 36 i 37. Bardziej szczegółowe dane są w Anlage C do s. 36. W dalszym ciągu systematycznie wzrastał majątek kasy, osiągając sumę 1879173 TR. Sumy za 1872 rok zob. Drucksachen nr 2, s. 142 i załącznik Anlage D do s. 142. Majątek nieco spadł do sumy 1597686 TR.

47 Ibidem, Drfucksachen nr 21, s. 639. Tu także projekt budżetu kasy na 1873 rok (zarazem także na następny rok).
} 
TABELA 1. Wysokość sum na wydatki administracyjne w dyspozycji kasy pożyczkowej

\begin{tabular}{|c|c|c|}
\hline \multirow{2}{*}{$\begin{array}{c}\text { Sejm (numer i rok } \\
\text { budżetowy) }\end{array}$} & \multicolumn{2}{|c|}{ Sumy budżetowe (na koniec grudnia) } \\
\cline { 2 - 3 } & Wpływy & Wydatki \\
\hline XIII (1856) & 6860 TR & brak danych TR \\
XIV (1858) & 6840 & 5796 \\
XIV (1859) & 6860 & 6403 \\
XVI (1861) & 6815 & 4336 \\
XVI (1862) & 6815 & 5721 \\
XVI (1863) & 6815 & 5786 \\
XX (1864) & 6715 & brak danych \\
XXI (1865 i 1866) & 6365 & brak danych \\
XXII & 580790 RM & brak danych \\
XXIII & 671234 & 28 090 \\
\hline
\end{tabular}

TABELA 2. Bilans kasy (wartość gotówki, papierów wartościowych i innych dokumentów)

\begin{tabular}{|c|c|c|}
\hline Sejm (rok) & $\begin{array}{c}\text { Aktywa (stan na koniec } \\
\text { grudnia) }\end{array}$ & $\begin{array}{c}\text { Pasywa (stan na koniec } \\
\text { grudnia) }\end{array}$ \\
\hline XIV (1858) & 5098400 & 4580720 \\
XV (1859) & 5123702 & 4590423 \\
XVI (1860) & 4947232 & 4394182 \\
XVI (1861) & 4696485 & 4114322 \\
XVIII (1862) & 4424379 & 3816201 \\
XVIII (1863) & 4231857 & 3590983 \\
XX (1864) & 3956370 & 3281151 \\
XX (1865) & 3610811 & 2903098 \\
XX (1866) & 3646193 & 2907464 \\
XX (1867) & 3603049 & 2868544 \\
XXII (1868) & 3516305 & 2742399 \\
XXII (1869) & 3162166 & 2351309 \\
XXII (1870) & 1842691 & 989334 \\
XXIII (1871) & 1879173 & 889717 \\
XXIII (1872) & 1597686 & 942254 \\
\hline
\end{tabular}




\section{SUMMARY}

\section{Establishment of provincial loan office on Silesia in 1854}

Humans have been beleaguered by floods since centuries, for there is a description of deluge, which is even immortalized in Bible. Also Silesia has been afflicted with them for hundreds of years, they repeated periodic in every century. Floods afflicted Silesia in 18th century and took place mostly after Prussia had seized the power. The first statutory regulation was the effect of these dangerous natural phenomena, thus it was to protect from floods. Nonetheless it wasn't perfect, as some troubles appeared during 19th century. However the flood from 1854 was the first that wreaked real havoc: deluge of Wroclaw city came in the aftermath of this event. The range of flooded areas forced the provincial authorities (Provinziallandtag) to take action in order to improve the situation. So called Provinziallandtag was the most significant element of the self-government, which had been formed in Prussia at the time. Therefore it is worth reminding about most important circumstances of its establishment in 19th century. Setting state, provincial loan office was initiative of 11th provincial authorities in 1854. It developed a project of statut and the amount of securities, which were to be an object of transaction. It was one of the best prepared petitions from 1851-1873. Desperate situation of provincial economy was the main reason of setting the loan office (previous attempts at improving the situation appeared to be fruitless and only temporary). Members of parliament thought that it had been necessary to create a new credit institution, as the loan office had not played its role so far. The floods from 1850s, which ruined the economy were the main reason of hard economic situation of province. Financing the repair of infrastructure required huge amounts of money, which could be gained from credits with profitable interest. These were not guarantied by bank sector, thus it was agreed that this task might be undertaken by an institution of self-government, supported by subsidies. The main part of publication deals with system of office, its financial politics, its main trappings of business.

There are charts in this work, which stands for financial situation of office.

Key-words: Silesia, 19th century, provincial selfgovernment, financial institution, lending money, financial politics, floods, supporting payment 